Акушерство та гінекологія

УДК $618.3-06: 613.24$

\author{
®Л. Б. Маркін, А. І. Попович, У. С. Прокіп \\ Львівський національний медичний університет імені Данила Галищьького
}

\title{
КОРЕКЦІЯ НУТРИТИВНОЇ МАГНІЄВОЇ НЕДОСТАТНОСТІ У ПРЕГРАВІДАРНОМУ ПЕРІОДІ
}

КОРЕКЦІЯ НУТРИТИВНОЇ МАГНІЄВОЇ НЕДОСТАТНОСТІ У ПРЕГРАВІДАРНОМУ ПЕРІОДІ. ОбґрУНТОВана доціЛЬНість лікування нутритивної магнієвої недостатності з метою зниження частоти і важкості ускладнень гестаційного процесу. Встановлено, що використання дієтичної добавки «Biolectra» (Hermes, Німеччина) забезпечує ефрективну корекцію гіпомагніємії в прегравідарному періоді.

КОРРЕКЦИЯ НУТРИТИВНОЙ МАГНИЕВОЙ НЕДОСТАТОЧНОСТИ В ПРЕГРАВИДАРНОМ ПЕРИОДЕ. ОбосНОВаНа необходимость лечения нутритивной магниевой недостаточности с целью снижения частоты и тяжести осложнений гестационного процесса. Установлено, что использование диетической добавки «Biolectra» (Hermes, Германия) обеспечивает эффективную коррекцию гипомагниемии в прегравидарном периоде.

CORRECTION OF NUTRITIONAL MAGNESIUM DEFFICIENCY IN PRENATAL PERIOD. The expedience of the therapy of nutritional magnesium therapy was proved to reduce the frequency and severity of complications of gestational process. It was established that the use of dietary supplement «Biolectra» (Hermes, Germany) provides an effective correction of hypomagnesemia in prenatal period.

Ключові слова: магнієвий дефріцит, прегравідарний період, дієтична добавка «Biolectra».

Ключевые слова: магниевый дефицит, прегравидарный период, диетическая добавка «Biolectra».

Key words: magnesium deficiency, prenatal period, dietary supplement «Biolectra».

ВСтУП. Оцінка ролі харчування вагітних та жінок, які планують вагітність, радикально змінилась в останні декілька десятиліть. Повноцінне харчування до та в період вагітності має велике значення, адже воно не лише забезпечує енергетичні потреби організму матері, але й є субстратом для розвитку тканин плода, а також створює енергетичний резерв для лактації. Повноцінне потрапляння харчових інгредієнтів в організм жінки в період преконцепції - основний чинник, який визначає стан її здоров'я та формує оптимальну програму розвитку плода [4, 9].

Магній - елемент, який бере участь у більшості ключових фізіологічних процесів, не синтезується самостійно в організмі людини і тому надходить тільки з їжею. Але, на жаль, за останні десятиріччя через неправильне харчування ми стали отримувати магнію значно менше. У сучасному раціоні дуже мало продуктів з максимальним вмістом магнію - нерафінованих злакових, риби, морепродуктів, свіжих фруктів та овочів. Під час заготовки продуктів для зберігання (сушіння, консервування та ін.) концентрація магнію знижується незначно, але його біодоступність різко знижується. Ситуацію погіршує система fast food, основу якої складає рафінована їжа, надлишок солі та цукру, а також продукти, які виводять магній з організму - наприклад, ортофосфорна кислота в кока-колі та лимонадах, різноманітні консерванти тощо $[2,8]$.

Відповідно до рішення Міжнародної експертної ради «Дефріцит магнію в акушерстві та гінекології» (Австрія, 2013), нижньою допустимою межею рівня магнію у плазмі крові $€$ значення в діапазоні 0,80-0,85 ммоль/л.

Значення рівня магнію в плазмі крові нижче за 0,80 ммоль/л розцінюється як дефіцит магнію (діагноз E61.2 за MKX-10) і асоціюється із статистично вірогідним підвищенням ризику таких ускладнень гестаційного процесу, як невиношування вагітності, гіпертензивні розлади під час вагітності, плацентарна дисфрункція, аномалії пологової діяльності, тромбоутворення [3, 5-7]. Цей біологічно активний елемент відіграє важливу роль у багатьох процесах життєдіяльності організму, бере участь у процесах гальмування міжнейронної і нейром'язової передачі, є регулятором клітинного росту, синтезу білкової молекули, енергозалежних процесів, трансмембранного переносу іонів та інших. Нестача магнію викликає спазм судин, зміни електролітного балансу, є причиною порушень психоемоційного стану $[2,7]$.

Останнє обумовлює доцільність своєчасної діагностики і корекції магнієвого дефіциту у жінок на етапі ПідГОТОВКИ ДО ВагітНОсті.

МАТЕРІАЛИ ТА МЕТОДИ. Групу спостереження склали 50 жінок репродуктивного віку з гіпомагніємією (концентрація магнію в плазмі крові < 0,80 ммоль/л).

Шлюб не був зареєстрованим у $8,0 \%$ жінок. Невисокий соціальний рівень відмічений у $24,0 \%$ спостережень. Зловживали тютюнокурінням 10,0\%, алкоголем - 2,0 \% вагітних. Контакт з професійними шкідливостями мали 18,0 \% жінок. Зріст 150 см і менше відмічений у $6,0 \%$, астенічна конституція - у 10,0 \% спостережень. Порушення менструального циклу відмічені у $26,0 \%$. Анамнез 14,0 \% жінок був обтяжений спонтанними абортами, 10,0 \% - завмерлою вагітністю, 8,0 \% - передчасними пологами, 8,0 \% - народженням дитини 3 малою масою тіла, 4,0\% - мертвонародженням, $6,0 \%$ - неплідністю, 26,0 \% - запальним процесом внутрішніх статевих органів. Гіпоплазію матки встановлено у $6,0 \%$, вади розвитку матки - у 4,0\% жінок. Операцію на матці перенесли $4,0 \%$, на маткових трубах $6,0 \%$, на яєчниках - $8,0 \%$ жінок. У 22,0 \% вагітних 


\section{Акушерство та гінекологія}

діагностовано легкого ступеня залізодефіцитну анемію, у 6,0 \% - вади серця без порушення кровообігу, у $8,0 \%$ - вегето-судинну дистонію, у 4,0 \% - захворювання нирок, у 8,0 \% - ендокринопатії.

Психоемоційний стан жінок та ефективність лікування вивчали за методикою анкетного опитування. Реєстрували симптоми магнієвого дефіциту (серцебиття, загальна стомлюваність і сонливість, почуття тривоги і страху, парестезії, судоми м'язів, закрепи).

Рівень магнію визначали колориметричним методом з використанням аналізатора Cobas 600 (с 501 модуль) і тест-системи Roche Diagnostics (Швейцарія).

Для здійснення нутритивної підтримки у випадку гіпомагніємії застосовували дієтичну добавку «Biolectra» (Hermes, Німеччина), одна доза якої містить 535 мг оксиду магнію (що відповідає 300 мг $\mathrm{Mg}^{2}+$ ). «Biolectra» призначали по 1 пакетику 1 раз на день 2 тижні з перервою 2 тижні впродовж 3-х місяців.

Результати опрацьовували методами варіаційної статистики за допомогою стандартних пакетів програм Microsoft Excel 2007 з використанням t-критерію Стьюдента; результати наведені у вигляді середніх значень і стандартної похибки середніх значень $(\mathrm{M} \pm \mathrm{m})$, рівень $\mathrm{p}<0,05$.

РЕЗУЛЬТАТИ ДОСЛІДЖЕННЯ ТАЇХ ОБГОВОРЕНня. Дослідження вікових показників вагітних групи спостереження показало, що 62,0 \% з них були у віці від 18 до 29 років, 32,0 \% - у віці від 30 до 40 років і $6,0 \%$ - понад 40 років.

Проведені дослідження показали, що у жінок 3 дефріцитом магнію серцебиття спостерігалось у $26,0 \%$; порушення сну - у 28,0\%; підвищений рівень тривожності - у $36,0 \%$; парестезії - у 48,0 \%; судоми м'язів - у 22,0 \%; закрепи - у 26,0 \% випадків. Слід зауважити, що не у всіх жінок були клінічні ознаки магнієвого дефіциту, у 6 пацієнток гіпомагніємія перебігала безсимптомно.

Середнє значення концентрації магнію у пацієн-

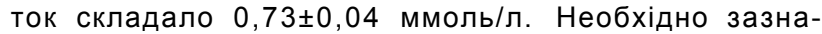

чити, що зниження концентрації магнію в крові свідчить про наявність вираженого магнієвого дефіциту, оскільки підтримання його нормального вмісту $€$ можливим впродовж певного часу за рахунок виходу магнію із депо кісток. Як наслідок, нормомагніємія не виключає можливої реальної гіпомагніємії. Саме тому особливо важливо звертати увагу на симптоми дефріциту магнію і вчасно проводити їх корекцію $[4,8]$.

Використання «Biolectra» у випадку нутритивної магнієвої недостатності забезпечувало ефективну корекцію гіпомагніємії у жінок.

Після проведеного курсу лікування дієтичною добавкою «Biolectra» кількість скарг зменшилася, всі пацієнтки відмічали поліпшення самопочуття. Так, через 2 тижні після початку лікування на загальну стомлюваність, сонливість скаржилися 5 (10,0\%) жінок, через 3 місяці - 1 (2,0\%); зменшувалось почуття тривоги і страху в 11 (22,0\%) та 5 (10\%) пацієнток, відповідно, через 2 тижні та 3 місяці; серцебиття - у $8(16,0 \%)$ та $3(6,0 \%)$; закрепи - у $7(14,0 \%)$ та 5 $(10,0 \%)$ відповідно. Судоми м'язів через 2 тижні після початку лікування відмічали 6 (12,0 \%) жінок, через 3 місяці судоми м'язів не турбували пацієнток; спостерігалися залишкові явища парестезії через 3 місяці лише у $6(12,0 \%)$ жінок (рис. 1).

Спостереження показали, що після прийому запропонованої терапії протягом 3-х місяців у жінок відбувалося збільшення вмісту магнію в сироватці крові. До лікування показник магніємії складав $0,73 \pm 0,04$ ммоль/л, через 2 тижні після початку лікування - 0,78 $\pm 0,04$ ммоль/л ( $>>0,05)$; після 3-х місяців

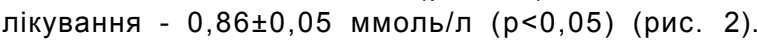

Пацієнтки відзначали добру переносимість «Biolectra». Побічні ефекти використання дієтичної добавки не спостерігались.

Високі темпи приросту рівня сироваткового магнію при лікуванні гіпомагніємії передусім пояснюються високим вмістом у дієтичній добавці «Biolectra» двовалентного магнію - оксиду магнію.

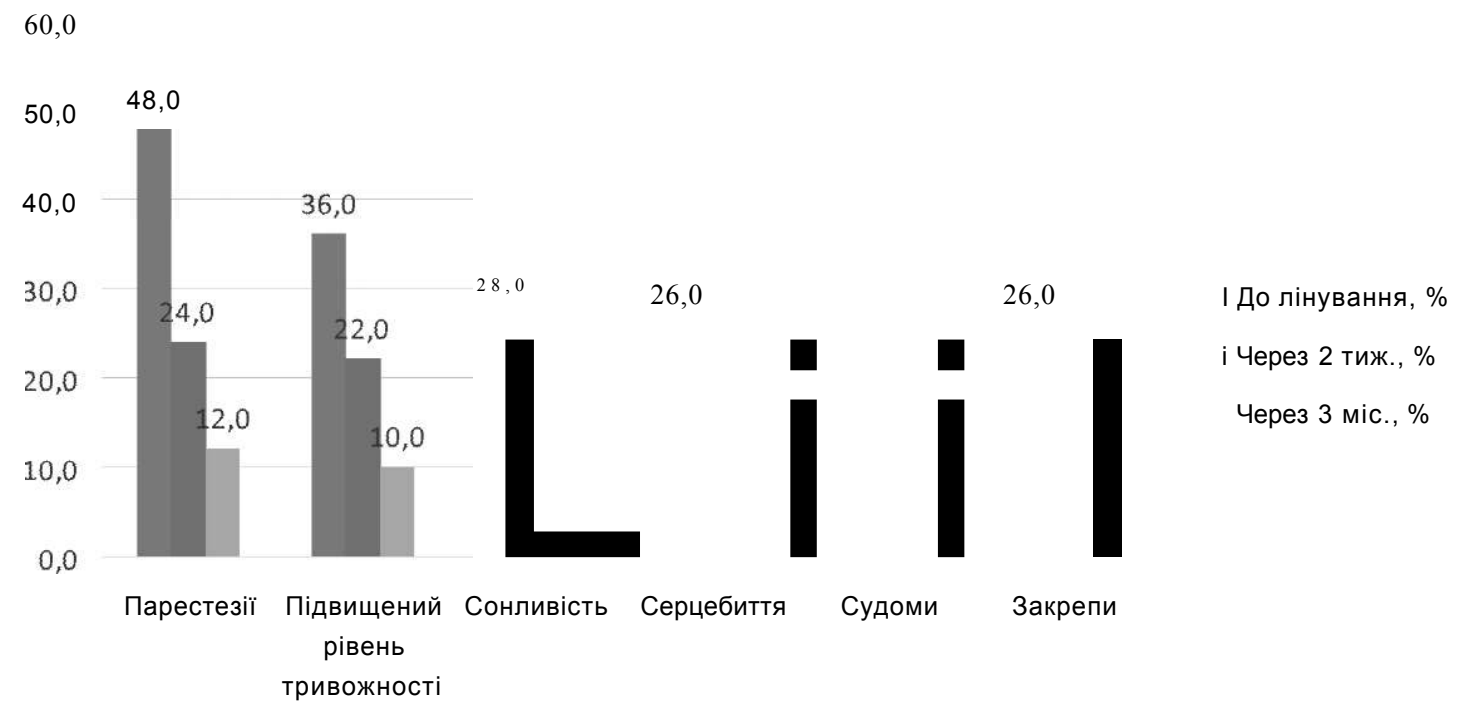

Рис. 1. Клінічні симптоми впродовж лікування дієтичною добавкою «Biolectra» $(n=50 ; p<0,05)$. 


\section{Акушерство та гінекологія}

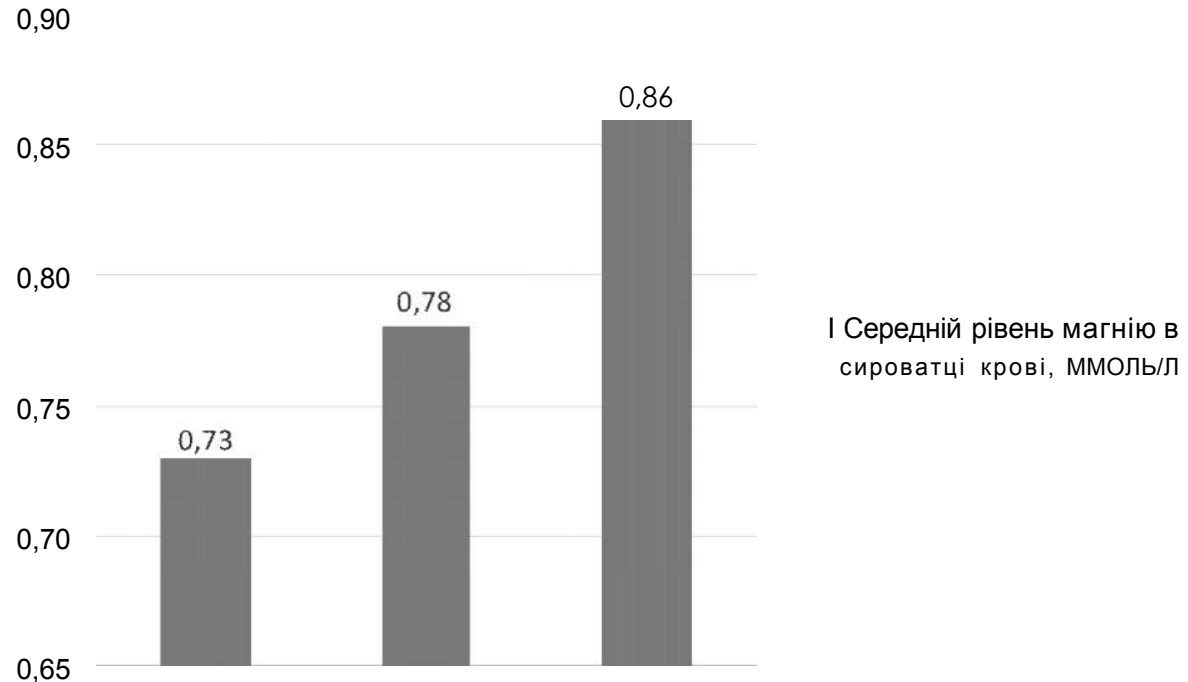

Рис. 2. Показники рівня магнію в сироватці крові впродовж лікування дієтичною добавкою «Biolectra» $(n=50 ; \quad p<0,05)$.

Таким чином, у результаті проведеного лікування дієтичною добавкою «Biolectra» підвищення рівня сироваткового магнію було відмічено в усіх 50 пацієнток. Вміст магнію утримувався на рівні здорових

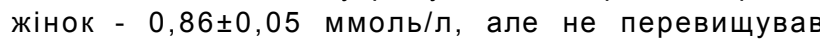
його, що може свідчити на користь того, що зайвий магній, імовірно, виводиться нирками. Це дозволяє широко використовувати магнієвмісні препарати, без тривоги про надмірне його накопичення в організмі.

ВИСновкИ. 1. Дефріцит магнію є суттєвим чинником ризику ускладненого перебігу вагітності.
2. Ефективну корекцію гіпомагніємії у прегравідарному періоді забезпечує використання дієтичної добавки «Biolectra».

ПЕРСПЕКТИВИ ПОДАЛЬШИХ ДОСЛІДЖЕНЬ. ТаКі ускладнення гестаційного процесу, як гіпертензивні розлади під час вагітності, плацентарна дисфункція, прееклампсія, тромбоутворення, пов'язані з недостатністю магнію, вимагають визначення доцільності призначення магнієвмісних препаратів у прегравідарному періоді жінкам з серцево-судинними захворюваннями.

\section{СПИСОК ЛІТЕРАТУРИ}

1. Громова О. А. Молекулярные механизмы воздействия магния на дисплазию соединительной ткани / О. А. Громова // Журнал для практикующих врачей. - 2008. - №1. - С. 23-32.

2. Громова О. А. Магний в акушерстве и гинекологии: история применения и современные взгляды / О. А. Громова, В. Н. Серов, И. Ю. Торшин // Трудный пациент. - 2008. - № 8. - С.10-15.

3. Грязнов Д. А. Роль дефицита магния в патогенезе метаболического синдрома / Д. А. Грязнов, М. В. Мельник, А. О. Осия // РМЖ. - 2008. - Т.16, № 21. - С. 23-28.

4. Дубоссарская 3. М. Современный взгяд на этиопатогенез, диагностику и лечение невынашивания беременности / 3. М. Дубоссарская // Медицинские аспекты здоровья женщины. - 2012. - № 6-7. - С. 12-16.
5. Магний при патологии беременности и родов / О. П. Алексеева, А. В. Клеменов, О. И. Гусева [и др.] // РМЖ. - 2004. - №1. - С. 30-34.

6. Фофанова И. Ю. Дефицит магния и его связь с акушерской практикой / И. Ю. Фофанова // Медицинский совет. - 2013. - № 5. - С. 31-36.

7. Magnesium sulfate in obstetrics: current data / E. Azria, V. Tsatsaris, F. Goffinet [etal.] //J. Gynecol Obstet Biol Reprod. - 2004. - Vol.12, № 33. - P. 510-517.

8. Bruno V. Antidegenerativ effects of $\mathrm{Mg} 2+$ valproate in cultured cerebellar neurons/ V. Bruno// Funct. Neirol. - 2010. - Vol.10, № 10. - P.121130.

9. Robboy S. Pathology of the Female Reproductive Truct / S. Robboy, M. Anderson, P. Russel. - Churchill Livingstone, 2002. - 929 p. 